\title{
Probable evidence of a Middle Palaeolithic site in the northern parts of the Susiana Plain, Khuzestan, Iran
}

\author{
Saeid Bahramiyan 1,2 \\ 1 Department of Archaeology, Faculty of Literature and Humanity, University of Tehran, Tehran, IR \\ 2 Laboratoire Archéorient, Maison de l'Orient et de la Méditerranée, Jean Pouilloux, \\ L'université Lumière Lyon 2, Lyon, FR \\ Bahramiyan.Saeid@gmail.com
}

\begin{abstract}
There is a considerable body of studies regarding the activities of the Pleistocene human population in the Zagros and Alborz regions of Iran, as well as significant progress in the Palaeolithic studies in other regions, such as the foothills, plains and deserts' margins. However, some of these peripheral regions and foothills are still neglected, and the information about the Palaeolithic period in these areas is limited. Khuzestan province, especially its northern regions, is one of these unstudied regions, yet the limited information about this region seems very interesting. Khervali, located on the western foothills of the Zagros Mountains and on the northern heights of Susa, nearby the western bank of the Karkheh River, is one of the few Palaeolithic sites identified in recent years. The site was identified in 2012 and was systemically surveyed. Due to the extension of the site and the distribution of the artefacts, sampling all the site was not feasible, therefore, four sections of the site were chosen for taking the samples and a total of 330 stone artefacts were collected. The results of the techno-typology analyses, as well as the frequency of the flakes, the Levallois samples and different types of scrapers, revealed that the artefacts date to the middle Palaeolithic period, with considerable access to the local raw materials.
\end{abstract}

KEY WORDS - Khervali; Middle Palaeolithic; north of Susiana Plain; conglomerate formation; accessibility; raw material

\section{Verjeten dokaz o srednje paleolitskem najdišču $v$ severnem delu ravnine Susiana, Kuzestan, Iran}

IZVLEČEK - Številne študije se ukvarjajo z vprašanjem aktivnosti ljudi v času paleolitika v gorovju Zagros in regiji Alborz $v$ Iranu, velik pa je tudi napredek pri paleolitskih študijah na drugih območjih kot so predgorja, ravnine in obronki puščav. Ne glede na to še vedno ostajajo obrobna območja in predgorja, ki so manj raziskana in imamo o njih le malo podatkov iz časa paleolitika. Takšno območje je tudi severni del Kuzestana, čeprav so ti podatki zelo zanimivi. Eno redkih prepoznanih paleolitskih najdišč je Kervali, ki se nahaja v zahodnem predgorju Zagrosa in na severnih višavjih Suse. Najdišč je bilo odkrito in sistematično raziskano leta 2012. Je zelo veliko in ima veliko površinskih artefaktov, kar pomeni, da ni bilo moč izvesti vzorčenja na celotni površini, ampak smo le-to razdelili na štiri dele in pobrali 330 kamnitih artefaktov. Na podlagi rezultatov tehnološko-tipološke analize, pogostnosti kamnitih odlomkov, vzorcev orodij, izdelanih z Levallois tehniko in različnih praskal, smo lahko najdbe datirali v čas srednjega paleolitika in sklepamo, da so imeli takratni ljudje dober dostop do lokalnih surovin.

KLJUČNE BESEDE - Kervali; srednji paleolitik; severni del ravnine Susiana; formacija konglomerata; dostopnost; surovina 


\section{Introduction}

Despite one century of studies of the Palaeolithic period in Iran, there are still many regions which have remained less known compared to the Zagros and Alborz mountainous areas. Khuzestan province is one of these unknown areas, specially its northern and north-western regions, with the exception of the Pabdeh cave excavation (Girshman 1949; 1951; 1993.10). There have been several reports about the Palaeolithic finds in recent years (Dinarvand et al. 2012; Dinarvand, Mehranpour 2015; Ahmadzadeh Shouhani 2014; Sheykh no date; Alipour 2012; 2014; Alipour, Nadali Kahish 2014), although most of the archaeological research in southwestern Iran and Khuzestan province is focused on the more recent prehistoric and historical periods, and only few archaeological studies are dedicated to the Palaeolithic. As a result, our knowledge about the Palaeolithic period compared to the more recent periods of this region is incomplete, while Palaeolithic studies of areas such as Zagros and Albourz tend to be more advanced compared to those of Khuzestan province.

An archaeological survey was conducted in 2012 by Loqman Ahmadzadeh Shouhani (Ahmadzadeh Shouhani 2014), on the western bank of Karkheh River (the city of Susa) with the aim of identifying and registering archaeological sites in the area. The survey produced 72 new sites that were identified and recorded. One of the identified sites was a valley known as 'Khervali' with a considerable distribution of stone artefacts, which makes it the first and only known

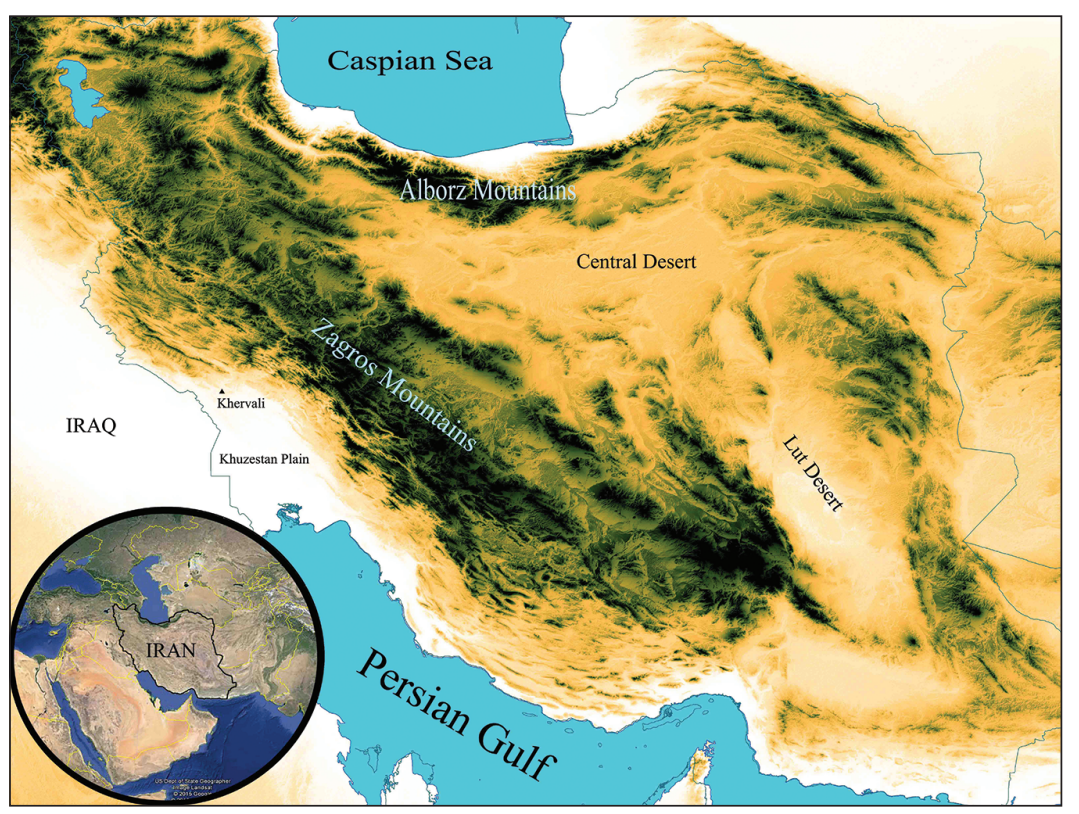

Fig. 1. Map showing the geographic location of Khervali site in the northern Khuzestan Plain.
Palaeolithic site on the western side of Karkheh River and also one of the few Palaeolithic sites of the northern Susiana plain (Fig. 1).

Regarding the lack of information about the Palaeolithic period of this region and the location of this site between the western foothills of Zagros and the plains, this site can be a major source of information about the Palaeolithic period of this region.

\section{Palaeolithic research background in the Khu- zestan Province}

Despite Palaeolithic studies starting in Iran more than a century ago by De-Morgan in the north of the territory (Vahdati Nasab 2011) there is little information about the Palaeolithic of the Iranian Plateau, and until the past few decades Palaeolithic studies in Iran were focused on the Alborz and Zagros mountainous areas. The Iranian plateau has many geomorphological variations, and the foothills, the margins of the plains and the deserts, in addition to the mountainous areas, have high value in terms of archaeological remains and studies, as suggested by the results of recent Palaeolithic studies (Vahdati Nasab et al. 2009; 2010; 2013; Vahdati Nasab, Hashemi 2016; Darabi et al. 2012; Biglari et al. 2000; 2009; Alibaigi et al. 2010; Shidrang 2009; Conard et al. 2009; Heydari Guran, Ghasidian 2011; Heydari Guran et al. 2009; 2015; Bahramiyan, Ahmadzadeh Shouhani 2016; Zeynivand 2017; Biglari 2004a; 2004b; Biglari, Shidrang 2016).

Unfortunately, Palaeolithic studies have not been the priority of archaeological research in Khuzestan province, and few studies have been conducted in this regard. This is despite the location of this region on the west of Zagros mountains and the accessibility of environmental resources such as permanent rivers, plains, mountainous regions, hills and foothills, all of which can be considered as significant factors in attracting Pleistocene human populations.

Roman Girshman conducted the Early Palaeolithic studies in Khuzestan in Pebdeh cave, located in the Lali region (northern Khuzestan), and he discovered seve- 
ral simple stone artefacts (Girshman 1949; 1951; 1993.10.465, Fig. 1). The next major study was conducted by Henry T. Wright (1979) in the north-eastern region of Khuzestan, in Gol and Iveh plains, as part of the rescue project of the archeological sites behind the Shahid Abbadpour (formerly Reza Shah) dam. As a result of his study a number of Palaeolithic and also more recent prehistoric and historical periods were discovered.

In 2004, a survey in Izeh was conducted by Cyrus Barfi and a rock shelter near the Eshkaft-e Kulfarah was identified with the same name and a total of 27 stone artefacts from The upper Palaeolithic and Epipalaeolithic were discovered (Barfi 2010). During the follow-up surveys conducted by Mozhgan Jayez in 2007 (Jayez 2007), the Izeh region was surveyed once again for Palaeolithic remains, and 54 sites including caves and rock shelters with stone artefacts dating back to the Epipalaeolithic and Early Neolithic were discovered, and their distribution patterns studied (Niknami et al. 2009; Niknami, Jayez 2008). Jayez conducted another archaeological survey in 2008 on the Pion plain, located in the northwest of the Izeh plain, in order to identify and register all of the archaeological sites, and as the result she identified 19 sites from the upper Palaeolithic to Epipalaeolithic period (Jayez et al. 2012; 2013).

The northern and north-western regions of Khuzestan province (e.g., northern piedmonts of the cities of Susa and Dezful) have attracted some Palaeolithic researchers in recent years, which has resulted in the identification of many Palaeolithic sites and remains. In 2008, Mohammad Sheyk conducted the first survey with the aim of identifying and studying the Palaeolithic settlement patterns on the eastern banks of Karkheh River, and he discovered 5300 stone artefacts from different Palaeolithic periods (Sheykh, publication year is not available; Vahdati Nasab, pers. comm.), which revealed the significance of the region during this time. The results of the previous Palaeolithic studies in northern Khuzestan (north of the Susiana plain) also show the importance of this less known region in this period. Another survey was conducted in 2010 by Yusef Dinarvand on the eastern banks of the Dez River, on the northern heights of Dezful, in the Shahyun region, and two lower and middle Palaeolithic sites, with stone artefacts such as cores, flakes, denticulate and Levallois pieces being discovered (Dinarvand et al. 2012; Dinarvand, Mehranpour 2015).

Despite the recent Palaeolithic surveys and excavations in Khuzestan plain, there are still many unknown and unstudied regions in the area that need to be examined, such as the western banks of the Karkheh River. In the intense study project of "The archaeological study of the western banks of Karkheh River" conducted by Loqhman Ahmadzadeh Shouhani in 2012, a number of artefacts and archaeological sites from the Palaeolithic, Chalcolithic and other recent periods were discovered (Ahmadzadeh Shouhani 2014). Of all the 72 identified sites, only the site at the Khervali Valley was attributed to the Palaeolithic period, due to the considerable distribution of stone artefacts. This valley is located to the north of the city of Susa and on the west of the Karkheh regulatory dam, which is the main subject of the present paper.

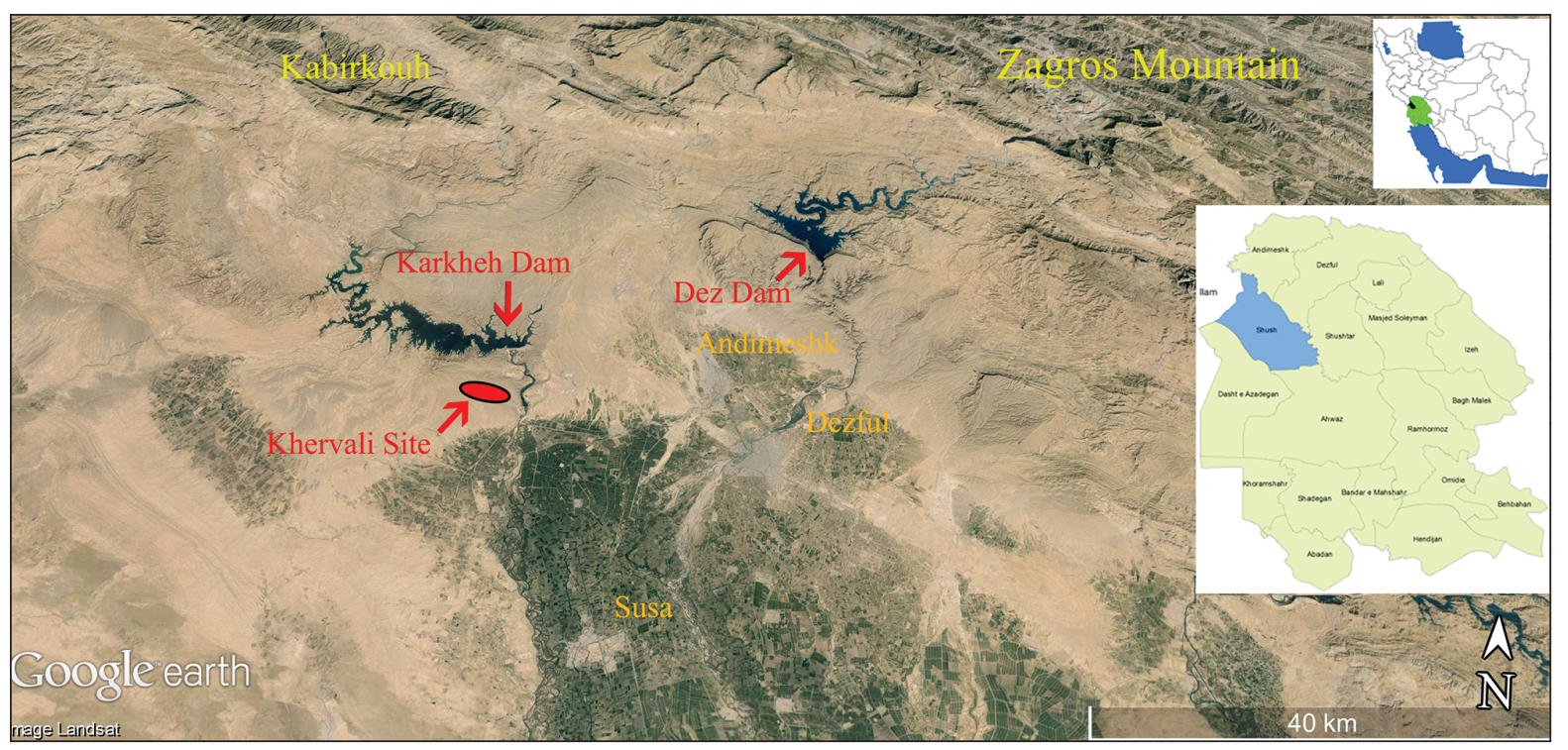

Fig. 2. The geographical position of the Khervali site in the Northern Susiana Plain. 
Alireza Sardari Zarchi also conducted another archaeological survey in October 2012, in the cities of Masjed Soleiman and Andika located in north-eastern Khuzestan province. This survey was part of the project of the archaeological map of Iran and resulted in discovering several Middle and Upper Palaeolithic and Epipalaeolithic sites (Sardari Zarchi 2013.68-86; 2014). Mehdi Alipour conducted another survey in 2013, with the objective of identifying and studying the settlement patterns of the Palaeolithic period in northern Khuzestan, Sardasht district, and on the north-eastern Dezful (Alipour 2012). He decided to conduct his survey in circular areas of $200 \mathrm{~m}$ diameter and managed to discover 1450 stone artefacts from 55 areas, and further studies showed the utilization of the Levallois technique in their production, dated back to the Middle Palaeolithic.

As mentioned above, the western bank of Karkheh River (in Susiana plain) is less known than the eastern bank of the river, and the few archaeological studies which have been conducted on this area are mostly focused on the more recent prehistoric and historical periods (e.g., Mecquenem 1943.141, Fig. 106; Adams 1962; Wenke 1975-76.13-221), the only study with relevant finds to the Palaeolithic period was conducted by Ahmadzadeh Shouhani, which resulted in the identification of the Khervali site and its Palaeolithic artefacts.

\section{The geographical location of Khervali}

The Khervali site with the geographical coordinates of N: $32^{\circ} 25^{\prime} 49.5529^{\prime \prime}, \mathrm{E}: 48^{\circ} 07^{\prime} 33.6804^{\prime \prime}$, and the dimensions of $2320 \times 630 \mathrm{~m}$ is located 130 to $160 \mathrm{~m}$ a.s.l. The site is situated to the north of the city of Susa, on the way of the connecting road between Andimeshk to Deh Luran, after the Naderi Bridge and $950 \mathrm{~m}$ from the western gate of the regulatory dam of Karkheh River (Fig. 2). The site is an open valley in terms of topographical characteristics and has a relatively flat surface with a slight north-western - south-eastern slope that forms several hills which are known as Khervali hills based on the geo-

\section{logical maps of Iranian Oil Company (Iranian Oil} Operating Companies DEZFUL 1967).

Based on the geological evidence, the high elevation of the site has preserved it from the sedimentation processes of the Khuzestan plain and sedimentary deposits of the Holocene period. Besides, the site is formed on the Bakhtyari Conglomerate Formation (Fig. 3), covered in round pieces of sandstone and chert stones. A seasonal river originates from the northern heights of the valley and flows through the centre of the site and finally joins the Karkheh River. The construction of the asphalt road at the middle of the valley in order to access the Karkheh dam and also the construction of a military barracks in the southern parts, as well as the extensive excavation operations by the dam's construction machinery, have done irreversible damage and destroyed the major sections of the site (Fig. 4).

\section{The survey methodology and the results}

The process of mapping and preparing a cross-sector plan of the site with mapping cameras was not possible due to the size of the site as well as the previously mentioned damage and destruction, with a lack of time also being an issue. Therefore, after an intensive and overall survey on the site and studying the concentration and distribution of the artefacts, four different sections were chosen for further studies and sampling. The selected sections were higher than the dried bed of the river and they were consequently preserved from the natural sedimenta- 
tion processes or human construction on the site. A circle with a diameter of $20 \mathrm{~m}$ was designated as the boundary of each section, their coordinates were registered via GPS devices and they were named Locus $1,3,4$ and 51 . The sampling was done by four different people in order to avoid personal bias or preconception in choosing the artefacts. Finally, a total number of 330 stone artefacts, including cores, core fragments, blank debitages, tools and debris were collected from the four selected sections (locus). Table 1 shows the number and the percentages of the collected artefacts.

\section{Palaeolithic artefacts}

As indicated in Table 1, among the 155 pieces of cores and core fragments, 37 pieces are the core, and 20 pieces are the core/chopper 2 , which are mainly made of rubble, and based on their frequency are divided into the three groups of flake cores (53 pieces), blade cores (two pieces) and bladelet cores (two pieces) that have been reduced by unidirectional and irregular techniques (Figs. 7-8). The abundance of fragment cores (98 pieces) among the assemblage was an interesting point in the artefacts of the site, which indicated that the core reduction and tool making process had been done on the site (Shen 1997.11).

Another 76 pieces of tools $(23.03 \%$ of the collected artefacts) included retouched pieces, notch/denticulate and some kinds of the scraper (Déjéte, single side scraper, heavy duty scraper and transverses) (Fig. 5). The flake tools, with a total number of 73 , or $96.05 \%$ of the tools, are the most abundant blank types of the collection, and then the two blades (2.63\%), and one bladelet (1.32\%), are the next most frequent collected tools. The limited number of the blades and bladelets is relevant to the rare frequency of blade cores (3.51\%) and bladelet cores (3.51\%) on the site (Fig. 6).

Besides the tools collected from the site that are produced by flaking

\begin{tabular}{|ccc|}
\hline Typology & Number & $\%$ \\
\hline Core/Core Frag. & 155 & 46.97 \\
\hline Debitage & 73 & 22.12 \\
\hline Tools & 76 & 23.03 \\
\hline Debris & 26 & 7.88 \\
\hline Total & 330 & 100 \\
\hline
\end{tabular}

Tab. 1. Number and percent of Khervali artefacts.

techniques from the core, a total of 73 blank debitages were also collected among the artefacts, and 71 pieces of these $(97.26 \%$ of the collected blank debitages) were produced by flaking techniques (except for several cases of the Lovallois technique) and two pieces $(2.74 \%)$ were produced by a blade removing technique from the core, and had been made with a similar technique to that seen with other tools and cores (Fig. O).

\section{Relative chronology of Khervali}

Based on the collected artefacts, and the lack of lower Palaeolithic indicating elements such as the Acheulean hand-axes or bifaces and picks, with the exception of existing core choppers and cores, and the abundant evidence of using the flaking and Lovallois techniques, as well as the frequency of scrappers and notch/denticulate in the collected items, and also the lack of upper Palaeolithic elements such as

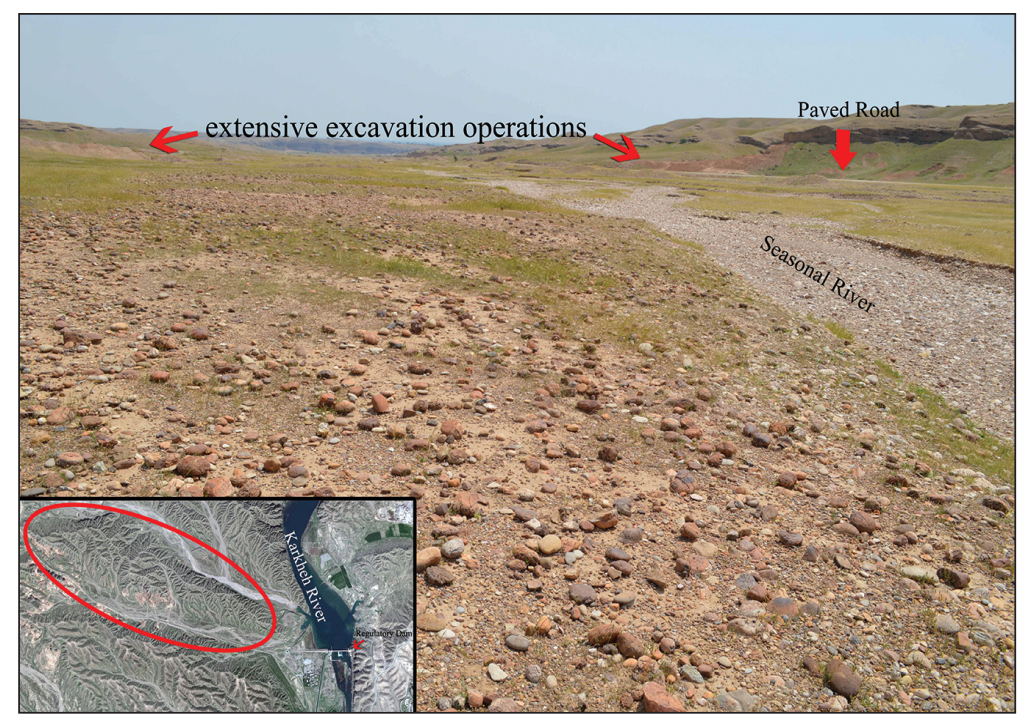

Fig. 4. Location of the Khervali Valley near the Karkheh River (left bottom), and a view of the middle part of the Khervali Valley (conglomerate landscape).

1 The section of Locus 2 is attributed to a collection of artefacts scattered on the dried river bed which passes through the Khervali Valley. Regarding the unsystematic nature of the survey and sampling, this collection was not mixed with other systematically collected artefacts.

2 Since the choppers are one of the major forms of cores (Shea 2013.50), the choppers are categorized as cores in the collected artefacts of this site. 


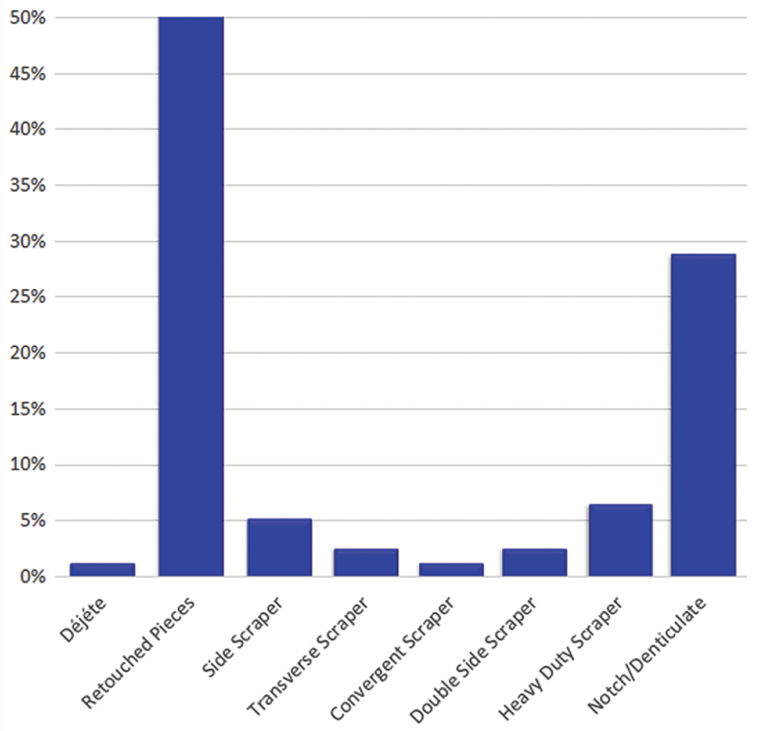

Fig. 5. Typology of the Khervali stone tools.

end scrapers, burin, high amount of retouched blades and Dufour3 (Olszewski, Dibble 2006.367), we believe that this site dates back to the middle Palaeolithic.

\section{The raw material resources}

The accessibility of the raw material resources was one of the key factors in choosing the location of prehistoric settlements (Heydari 2004). Therefore, studying the material and structure of the raw materials (stone) utilized to produce the tools and artefacts in the site, as well as the geological features

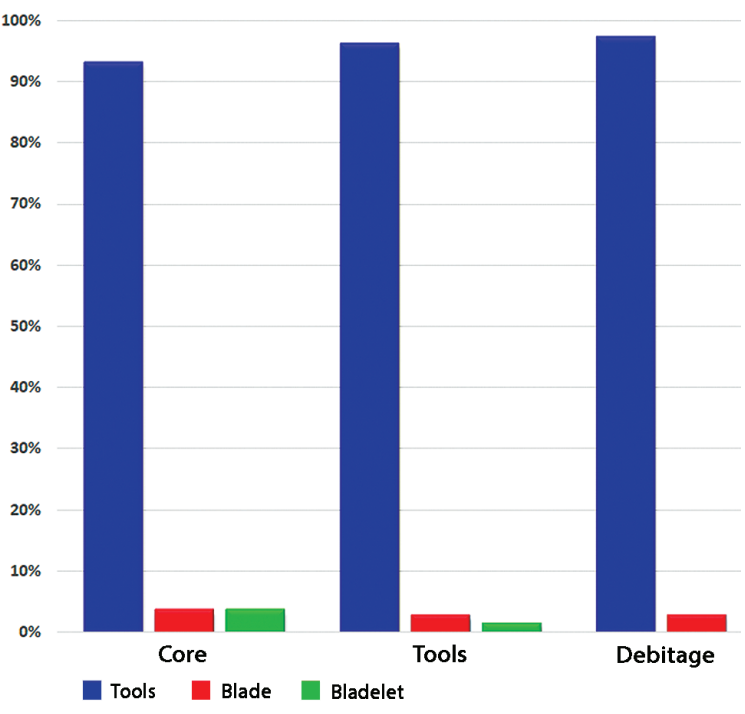

Fig. 6. The used techniques for core reduction and knapping in the Khervali site.

of each region, play major roles in finding out where the resources originated and also speculating about the exploitation methods in the prehistoric sites, specially Palaeolithic ones. Examining the collected stone artefacts in the present study revealed that the raw materials utilized in the Khervali Valley are mostly flint (pieces of chert, Jasper, Opal) and rarely river rubble like sandstone or quartz. Most of the artefacts are made of light brown or crimson flints, and in some cases green and red or grey and cream ones. These are the main lithological features of the Bakhtyari Conglomerate Formation ${ }^{4}$, dating back to the Cretaceous, Eocene and Oligocene geological peri-

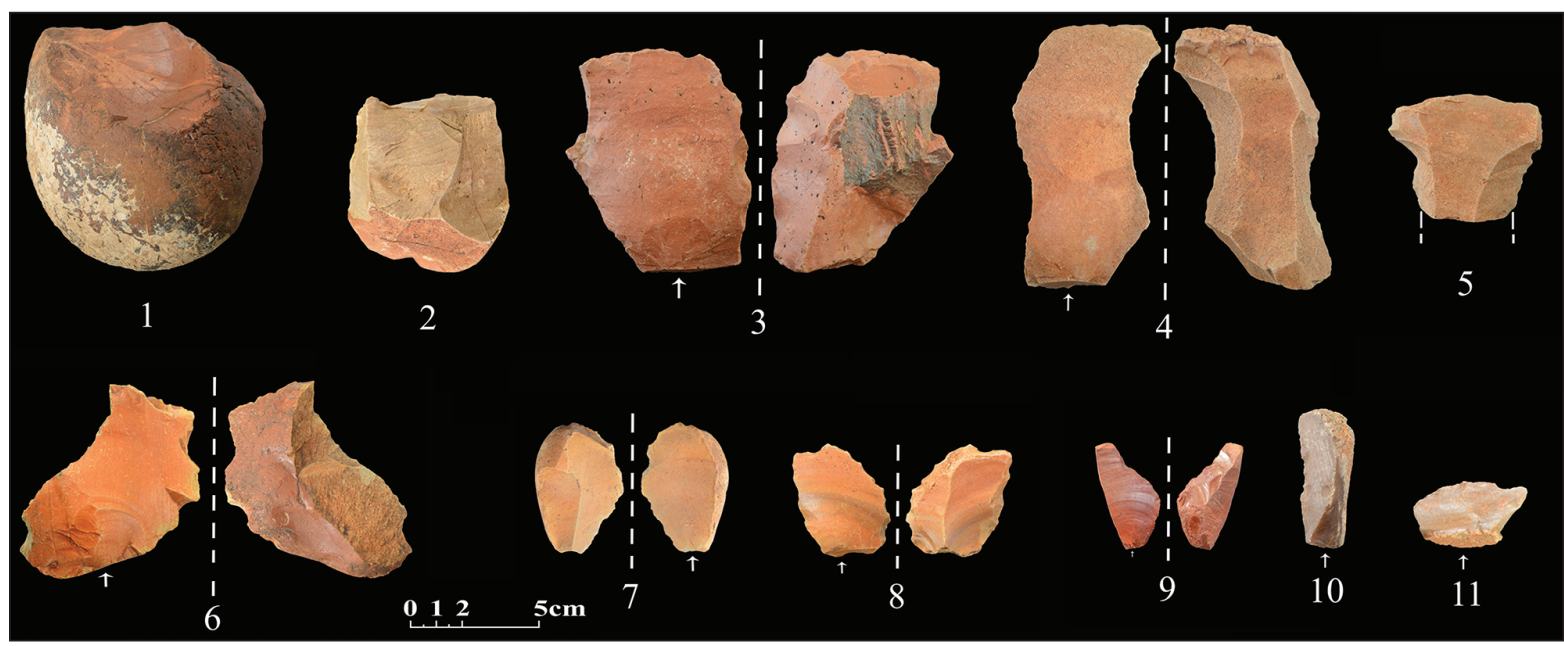

Fig. 7. Some of the collected artefacts from the Khervali site: 1 core/chopper; 2 flake core; 3 heavy duty scraper; 4-5 Levallois flake; 6-7 denticulate flake; 8 scraper with heavy retouch; 9 déjéte; 10 single-sided scraper; 11 transverse scraper.

3 It should be mentioned that the existence of blades and bladelets is not very surprising in the lower and middle Paleolithic periods (Wojtczak 2014.27-33).

4 This formation is named after the Bakhtyari tribe and is characterized by alluvial-foothill sediments derived from altitude erosion, including conglomerates and calcareous sandstones. 
ods (Darvishzadeh 1991.660), and their outcrops have been reported in the western Zogros mountains and the northern regions of Khuzestan, particularly in the northern parts of Susiana (Dinarvand, Mehranpour 2015; Bahramiyan, Ahmadzadeh Shouhani 2016), Deh Luran (Zeynivand 2017) and Mehran plains (Darabi et al. 2012). Besides the results of the precise typo-technological analyses on the stone artefacts of the Khervali site, which revealed the existence of a workshop with great accessibility to the raw materials (Bahramiyan 2015), this site is also located on the Bakhtyari Conglomerate Formation (Fig. 3), which obviously demonstrates the direct access of the settlers

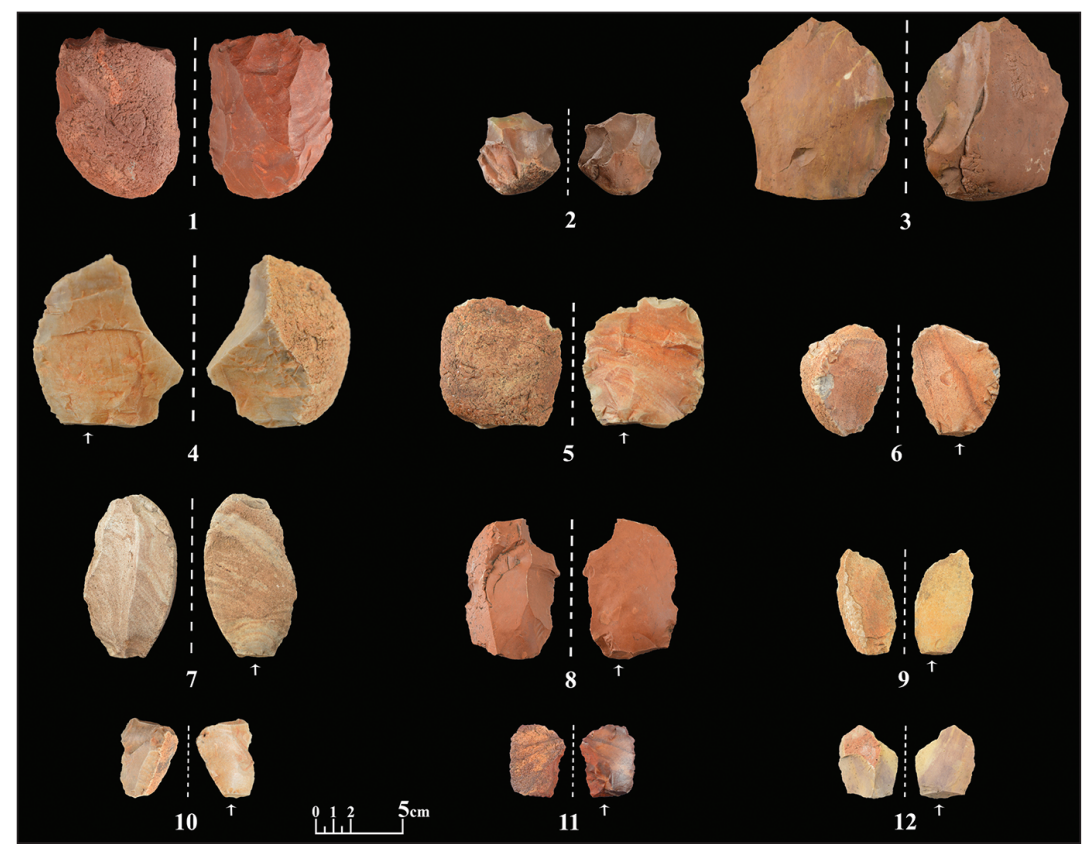

Fig. 8. Some of the collected artefacts from the Khervali site: 1 blade/bladelet core; 2 multidirectional bladelet core; 3 heavy duty scraper; 4, 5 and 12 cortical debitage; 6, 7, 9, 10, 11 retouched piece; 8 denticulate. to the raw material resources needed to produce their artefacts.

\section{Conclusion}

Despite one century of Palaeolithic studies in Iran, Khuzestan province is one of the regions that have remained in darkness, compared to more studied regions such as Zagros and Alborz. Khuzestan province in general, and its northern region (Susiana plain) in particular have in Iranian archaeological studies a major role, although Palaeolithic in the region, unlike the more recent periods, is not well studied. The little knowledge we have comes from recent studies, yet the results are very interesting and there are many reports about sites from different Palaeolithic periods, in Susiana plain and its northern regions such as the heights between the Susiana plain and western foothills of Zagros. The main points about these sites is their location nearby permanent and seasonal water resources, and on the Bakhtyari Conglomerate Formation in this interstitial area, which shows the relation between these sites and the accessibility to raw material sources, which could be reached often and easily in order to support tool-making activities. The recently discovered site of Kherveli is one of the rare identified Palaeolithic sites in the northern Susiana plain with two main features: its exceptional geographical location between the Zagros mountains and the lowlands of Khuzestan, an interstitial area whose Palaeolithic history is still un- known; second, the direct and definite relation of the location of the site with the accessibility to the raw materials on the Bakhtyari Conglomerate Formation, with its high density of raw materials. Therefore, it seems that more specialized and focused studies in these areas with the aim of the identification of Palaeolithic sites and analysing their settlement patterns from a wider perspective (the highlands and the plains) can result in significant finds on how the Pleistocene human populations distributed and adapted to their environment, as well as the patterns utilized in manufacturing stone artefacts, exploiting raw materials and the probable role of the location of the sites between the mountains and the plains. 


\section{References}

Adams R. M. 1962. Agriculture and Urban Life in Early Southwestern Iran. Science New series 136(3511): 109122.

Aghanabati S. A. 2006. Geology of Iran. Geological Survey and Mineral Explorations of Iran (GSI) Publication. Tehran. (in Persian)

Ahmadzadeh Shouhani L. 2014. Archaeological Survey of the Western Side of Karkheh River, Khuzestan, Iran. In Proceeding of the 12th Annual Symposium on the Iranian Archaeology, 19-21 May 2014. Iranian Center for Archaeological Research (ICAR). Tehran: 32-35. (in Persian)

Alibaigi S., Niknami K., and Khosravi S. 2010. A Preliminary Report on the Investigations of the Lower Paleolithic Site of Khaleseh in the Khoram Dareh Valley, Zanjan. Iranian Archaeology 1(1): 8-14.

Alipour M. 2012. Report of Survey and Discovery of Paleolithic Occupations in Northeastern Dezful. Cultural Heritage, Handicrafts and Tourism Organization of Khuzestan Province. (in Persian)

2014. Survey and Discovery of Paleolithic Occupations in Northeastern Dezful. Thesis Presented for the Degree of Master of Art (M.A) in Archaeology. Marlik University. Nowshahr. (in Persian)

Alipour M., Nadali Kahish M. 2014. Report of Survey and Discovery of Paleolithic Occupations in Northeastern Dezful. In Proceeding of the $12^{\text {th }}$ Annual Symposium on the Iranian Archaeology, 19-21 May 2014. Iranian Center for Archaeological Research (ICAR). Tehran: 310-312. (in Persian)

Bahramiyan S. 2015. Techno-typological Analysis of Stone Artefacts from KS1700 Site (Khervali Hills), Western of the Karkheh River (Khuzestan province). Thesis of Master of Arts in Archaeology. Tarbiat Modares University. Tehran. (in Persian)

Bahramiyan S., Ahmadzadeh Shouhani L. 2016. Between Mountain and Plain: New Evidence for the Middle Palaeolithic in the Northern Susiana Plain, Khuzestan, Iran. Antiquity 90(354): 1-6.

https://doi.org/10.15184/aqy.2016.190

Barfi S. 2010. Survey Report of a Rockshelter Containing Eppipaleolithic Eevidence in Kul Farah, Izeh. Bastanshenasi va Tarikh 46: 10-14. (in Persian)

Biglari F., Nokandeh G., and Heydari Guran S. 2000. A Recent Find of a Possible Lower Paleolithic Assemblage from the Foothills of the Zagros Mountains. Antiquity 74: 749750. https://doi.org/10.1017/S0003598X00060257

Biglari F. 2004a. The Discovery of the First Evidence of Middle Paleolithic Occupation at Nargeh in the Qazvin Plain in the Northwest Central Plateau of Iran. Archaeological Reports 2: 165-169. (in Persian)

2004b. The Preliminary Survey of Paleolithic Sites in the Kashan Region. In S. M. Shahmirzadi (ed.), The Silversmiths of Sialk (Sialk Reconsideration Project). Report No. 2. Iranian Center for Archaeological Research (ICAR). Tehran: 151-168. (in Persian)

Biglari F., Javeri M., Mashkour M., Yazdi M., Shidrang S., Tengberg M., Taheri K., and Darvish J. 2009. Test Excavations at the Middle Paleolithic Sites of Qaleh Bozi, Southwest of Central Iran, a Preliminary Report. In M. Otte, F. Biglari and J. Jaubert (eds.), Iran Palaeolithic/Le Paléolithique d'Iran. Actes 15e Congrés UISPP, Lisbonne, Sept. 2006, Vol 28, Session C15. British Archaeological Reports IS 1968. Archaeopress. Oxford: 29-38.

Biglari F., Shidrang S. 2016. New Evidence of Paleolithic Occupation in the Western Zagros Foothills. In K. Kopanias and J. MacGinnis (eds.), The Archaeology of the Kurdistan Region of Iraq and Adjacent Regions. Archaeopress Archaeology. Archaeopress Publishing Ltd. Oxford: 29-38.

Conard N. J., Ghasidian E., and Heydari Guran S. 2009. The Open-air Epipaleolithic Site of Bardia and Paleolithic Occupation of the Qaléh Gusheh Sand Dunes, Esfahan Province, Iran. In M. Otte., F. Biglari, and J. Jaubert (eds.), Iran Palaeolithic/Le Paléolithique d'Iran. Actes 15e Congrés UISPP, Lisbonne, Sept. 2006, Vol 28, Session C15. British Archaeological Reports IS 1968. Archaeopress. Oxford: 141-154.

Darabi H., Javanmardzadeh A., Beshkani A., and Jami-Alahmadi M. 2012. Paleolithic occupation of the Mehran Plain in Southwestern of Iran. Documenta Prehistorica 39: 443-451. https://doi.org/10.4312/dp.39.32

Darvishzadeh A. 1991. Geology of Iran. Danesh-e Emruz. Tehran. (in Persian)

Dinarvand Y., Mortazavi M., Mehranpoor H., Yazdanfar A., Alipoor M., Khodabakhshi Parizi M., and Ahmadzadeh Shohani L. 2012. A Paleolithic Survey around the Dez River in Southwestern Iran. In $4^{\text {th }}$ International Congress of the Society of South Asian Archaeology (4SOSSA). 1517 April 2012. Society of South Asian Archaeology. Zahedan: 43 . 
Dinarvand Y., Mehranpour H. 2015. Paleolithic Open-air Sites, North of Susiana Plain in South West Iran, Khuzestan Province, East of Dez River. Ancient Asia 6(6): 1-4.

Girshman R. 1949. Campagne de Fouilles á Suse en 19481949. Comptes Rendus des Séances de l'Académie des Inscriptions ET Belles-Lettres 3: 196-199.

\section{L'Iran des Origions a l'Islam. Payot. Paris.}

1993. Iran from the Earliest Times to the Islamic Conquest. Mohammad Moein, Elmi va Farhangi publication. Tehran. (in Persian)

Heydari S. 2004. Stone Raw Material Sources in Iran: Some Case Studies. In T. Stöllner., R. Slotta, and A. Vatandoust (eds.), Persiens Antike Pracht: Bergbau, Handwerk, Archäologie: Katalog der Ausstellung des Deutschen Bergbau Museums Bochum vom 28. November 2004 bis 29. Mai 2005. Deutsches Bergbau-Museum. Bochum: 124-129.

Heydari Guran S., Ghasidian E., and Conard N. J. 2009. Paleolithic Sites on Travertine and Tufa Formations in Iran. In M. Otte., F. Biglari and J. Jaubert (eds.), Iran Palaeolithic/Le Paléolithique d'Iran. Actes 15e Congrés UISPP, Lisbonne, Sept. 2006, Vol 28, Session C15. British Archaeological Reports IS 1968. Archaeopress. Oxford: 109-124.

Heydari Guran S., Ghasidian E. 2011. Paleolithic Survey in Arisman Region: Western Central Iranian Plateau. In A. Vatandoust., H. Parzinger and B. Helwing (eds.), Early Mining and Metallurgy on the Western Central Iranian Plateau. Archäologie in Iran und Touran Band 9. Verlag Plilip von Zebern. Mainz: 484-498.

Heydari Guran S., Ghasidian E., and Conard N. J. 2015. Middle Paleolithic Settlement on the Iranian Central Plateau. In N. J. Conard, A. Delagnes (eds.), Settlement Dynamics of the Middle Paleolithic and Middle Stone Age. Volume IV. Tübingen Publications in Prehistory. Kerns Verlag. Tubingen: 171-203.

Iranian Oil Operating Companies. 1967. Geological and Exploration Division (DEZFUL). Geological Compilation Map 1:100,000. Drawing No: 25470 W. Tehran.

Jayez M. 2007. Stone Age Sites of Izeh Plain: Discovery and Spatial Analysis. Thesis Presented for the Degree of Master of Art (MA) in Archaeology. University of Tehran. Tehran. (in Persian)

Jayez M., Niknami K., and Molla Mirzai Kh. 2012. Report on the Discoveries of New Stone Age Sites in the Plain of Pion, South Western of Iran. In $4^{\text {th }}$ International Congress of the Society of South Asian Archaeology (4SOSSA). 15-17 April 2012. Society of South Asian Archaeology. Zahedan: 46.
Jayez M., Mola Mirzai Kh., and Niknami K. 2013. Reporting the Stone Age Sites in Pion Plain. Iran Archaeology 4: 23-40. (in Persian)

Mecquenem R. De. 1943. Fouilles de Suse 1993-1939. Mémoires de la Mission Archéologique en Iran XXIX: 140142.

Niknami K., Jayez M., and Salahshour N. 2009. New Epipalaeolithic- Protoneolithic Sites on the Izeh Plain, Southwestern Iran. Antiquity Project Gallery 83(321). http://www.antiquity.ac.uk/projgall/jayez321/

Niknami K., Jayez. M. 2008. Spatial Patterning of Epipalaeolithic-Early Neolithic Site Structure of Izeh Plain, Southwestern Iran. In M. Ioannides., A. Addison., A. Georgopoulos., and L. Kalisperis (eds.), Digital Heritage Proceedings of the 14th International Conference on Virtual Systems and Multimedia, 20-25 October 2008. Limassol. Cyprus: 139-146.

Olszewski D., Dibble H. L. 2006. To be or not to be Aurignacian: The Zagros Upper Paleolithic. In 0. Bar-Yosef and J. Zilhao (eds.), Towards a Definition of the Aurignacian. Proceedings of the Symposium Held in Lisbon. 2530 June 2006. Instituto Portugues de Arqueologia. Portugal: 355-373.

Sardari Zarchi A. 2013. Report on an Archaeological Survey in Andika Township. Vol 2. Part 1. Cultural Heritage, Handicrafts and Tourism Organization of Khuzestan Province. (in Persian)

2014. Archaeological Survey in Masjed Soleyman and Andika Townships; an Example of Cultural Interactions between the Highlands of Zagros and Lowlands. In Proceeding of the 12th Annual Symposium on the Iranian Archaeology, 19-21 May 2014. Iranian Center for Archaeological Research. Tehran: 267-270. (in Persian)

Shea J. J. 2013. Stone Tools in the Paleolithic and Neolithic Near East. A Guide. Cambridge University Press. London.

Shen Ch. 1997. Towards A Comprehensive Understanding of the Lithic Production System of the Princess Point Complex, Southwestern Ontario. Unpublished PhD dissertation. University of Toronto. Canada.

Sheykh M. publication year is not available. A paleolithic survey in Susiana Plain, Karkheh River basin. Catalog published in Cultural Heritage, Handicrafts and Tourism Organization of Khuzestan Province. (in Persian)

Shidrang S. 2009. A Typo-Technological Study of an Upper Paleolithic Collection from Sefid-Ab, Central Iran. In M. Otte., F. Biglari, and J. Jaubert (eds.), Iran Palaeolithic/Le Paléolithique d'Iran. Actes 15e Congrés UISPP, 
Lisbonne, Sept. 2006, Vol 28, Session C15. British Archaeological Reports IS 1968. Archaeopress. Oxford: 47-56.

Vahdati Nasab H., Mollasalehi H., Saeedpour M., and Jamshidi J. 2009. Paleolithic Levalloisian Assemblages from Boeen Zahra in the Qazvin Plain, Iran. Antiquity Project Gallery 83 (320).

http://www.antiquity.ac.uk/projgall/nasab320/

Vahdati Nasab H., Roustaei K., and Rezvani H. 2010. Delazian (Mirak I): Evidence of Paleolithic Settlement at the Northern Edge of the Iranian Central Desert. In P. Matthiae, F. Pinnock, L. Nigro, and N. Marchetti (eds.), Proceedings of the $6^{\text {th }}$ Archaeology of the Ancient Near East, Vol. 2. 5-10 May 2008. Università di Roma 'La Sapienza'. Roma: 733-742.

Vahdati Nasab H. 2011. Paleolithic Archaeology of Iran. International Journal of Humianities 18(2): 63-87. http://journals.modares.ac.ir/article-27-1985-en.html

Vahdati Nasab H., Clark G. A., and Torkamandi S. 2013. Late Pleistocene Dispersal Corridors across the Iranian Plateau: A Case Study from Mirak, a Middle Paleolithic Site on the Northern Edge of the Iranian Central Desert (Dasht-e Kavir). Quaternary International 300: 267-281. https://doi.org/10.1016/j.quaint.2012.11.028
Vahdati Nasab H., Hashemi M. 2016. Playas and Middle Paleolithic Settlement of the Iranian Central Desert: The discovery of the Chah-e Jam Middle Paleolithic Site. Quaternary International 408: 140-152. https://doi.org/10.1016/j.quaint.2015.11.117

Wenke R. J. 1975-76. Imperial Investment and Agricultural Developments in Parthian and Sasanian Khuzestan: 150 B.C. to A.D. 640. Mesopotamia 10-11: 31-221.

Wright H. T. (ed.) 1979. Archaeological Investigations in Northeastern Xuzestan. 1976, Research Reports in Archaeology: (Research Reports in Archaeology) Contribution 5, Technical Report 10. Museum of Anthropology, the University of Michigan. Ann Arbor.

Wojtczak D. 2014. The Early Middle Palaeolithic Blade Industry from Hummal, Central Syria. Unpublished PhD Dissertation. Basel University. Basel.

Zeynivand M. 2017. An Acheulean Biface from the Deh Luran Plain, Iran. Antiquity 91(357): 1-5. https://doi.org/10.15184/aqy.2017.42

\section{back to contents}

